\title{
Physiology and pathology of the equine joint
}

\author{
P. R. van Weeren and P. A. J. Brama \\ Department of Equine Sciences, Faculty of Veterinary Medicine, Utrecht University, The Netherlands
}

\begin{abstract}
Summary
Diseases of the locomotor system are the most commonly encountered disorders in equine practice. Among them, joint-related ailments are most frequent. In this paper a synopsis is given of structure and function of the equine joint with the emphasis on molecular biochemistry. As examples of different pathologic aberrations osteoarthritis $(O A)$ and osteochondrosis $(O C)$ are dealt with. The paper concludes with a short overview of the current trends in equine synovial joint research and a suggestion of what the future might bring.
\end{abstract}

Keywords: Horse, joint, extracellular matrix, collagen, proteoglycans, osteoarthritis, osteochondrosis

\section{Physiologie und Pathologie des Pferdegelenkes}

Lahmheiten gehören zu den am häufigsten diagnostizierten Erkrankungen des Pferdes, wobei funktionelle Störungen eines oder mehrerer Gelenke die wichtigsten Probleme darstellen. Sowohl in der Human- als auch in der Veterinär- bzw. Pferdemedizin wird seit einigen Jahren auf dem Gebiet der Gelenkserkrankungen intensiv geforscht. Voraussetzung für das Verständnis der pathophysiologischen Zusammenhänge ist die Kenntnis des molekularen Aufbaus des Gelenkknorpels. Im vorliegenden Artikel wird ein Abriss des Aufbaus und der Funktion des Gelenkes, eine Synopsis der zwei wichtigsten Gelenkerkrankungen Osteoarthritis (OA) und Osteochondrosis (OC), sowie eine Übersicht über die wichtigsten Forschungsgebiete und ein Vorausblick auf die für die nahe Zukunft anstehenden wissenschaftlichen Untersuchungen vermittelt.

Das Gelenk besteht grundsätzlich aus zwei oder mehreren mit Gelenkknorpel bedeckten Knochenenden die miteinander artikulieren. Außer dem Knorpel (Chondrium) stellen auch der subchondrale Knochen, die Gelenkkapsel und die Gelenkflüssigkeit wichtige Teile des Gelenkes dar. Der Gelenkknorpel besteht aus 4 unterschiedlichen Schichten, in denen die Knorpelzellen jeweils eine andere Ordnung haben: die oberflächliche, mittlere und tiefe Schicht die von der kalzifizierten Schicht durch den sogenannten "Tidemark" getrennt sind.

Gelenkknorpel weist nur wenig Zellen auf und enthält keine Blutgefäße oder Nerven. Der größte Teil besteht dementsprechend aus der extrazellulären Grundsubstanz, deren Hauptkomponenten Kollagen, Proteoglykane und Wasser sind. Kollagen im Gelenkknorpel ist hauptsächlich Type II-Kollagen, das in großen Gewölbebögen angeordnet ist und so ein dreidimensionales Netz formt. In diesem Netz sind die Proteoglykanaggregate lokalisiert die durch ihre starke Sulfatierung und ihre deshalb negative Ladung stark wasseranziehend sind. In biomechanischer Hinsicht entsteht so ein zusammengesetztes Gewebe, in dem die expandierenden Kräfte der Proteoglykanaggregate von der Spannung im Kollagennetz neutralisiert werden. Diese Konstruktion verleiht dem Gewebe einen großen Widerstand gegen Druckkräfte (durch die Proteoglykanaggegate) und Zugkräfte (durch das Kollagen).

Obwohl Gelenkknorpel nur wenige Zellen hat, ist es ein metabolisch aktives Gewebe, in dem ein Gleichgewicht an anabolen und katabolen Faktoren wie Zytokinen und Wachstumsfaktoren herrscht, was die Instandhaltung und ununterbrochene Funktion des Gewebes ermöglicht. Die Ersatzgeschwindigkeit bei erwachsenen Individuen ist für die Proteoglykane niedrig (bis 5 Jahre für humanen Knorpel). Für das Kollagen schätz† man eine Ersatzgeschwindigkeit von 350 Jahre für den Menschen und 120 Jahre beim Hund.

Osteoarthritis (OA) und Osteochondrosis (OC) sind zwei sehr verschiedene Gelenkserkrankungen. OA stellt einen degenerativen Prozess dar, in dem das Gleichgewicht zwischen Verschleiß durch biomechanische Belastung und Ersatz der Bauteile der extrazellulären Grundsubstanz gestört ist. So entsteht ein Teufelskreis, in dem die geschädigte Grundsubstanz schon bei leichterer Belastung weiter geschädigt wird, dann eine weitere Verringerung des Widerstandes eintritt, was einer schnelleren Schädigung widerum Vorschub leistet. Die spezifische Ursache dieses Circulum vitiosus ist nicht ganz geklärt und wahrscheinlich auch nicht in allen Fällen gleich. In Betracht kommt eine, vielleicht erblich bedingte, mangelhafte Qualität des Knorpels, zu hohe Belastung und eine Synovitis, die durch hohe Produktion von Entzündungsmediatoren den Knorpel schädigt.

Die OC ist Ausdruck einer gestörten endochondralen Ossifikation. Aus diesem Grunde entsteht die Erkrankung zwangsläufig nur bei jungen, wachsenden Tieren, auch wenn sich das Problem möglicherweise erst im Erwachsenenalter klinisch manifestiert. Es ist sicher, dass bei der Entstehung einer Osteochondrosis mehrere Faktoren eine Rolle spielen, genetische sowie Umweltfaktoren. Es gibt hinsichtlich der Pathogenese dieses Leidens eine Reihe von Hypothesen und die Forschungen konzentrieren sich in der letzten Zeit auf die Molekulbiologie. Ernährungsfaktoren, wie die Fütterung hochenergetischen Futters oder Kupfermangel einerseits wie ein positiver Einfluss von Bewegung andererseits werden diskutiert. Jüngst wurde erkannt, dass OC beim jungen Fohlen einen sehr dynamischen Prozess darstellt, in dessen Verlauf röntgenologisch sichtbare Defekte entstehen können, die aber bei Erreichen eines bestimmten Alters auch wider völlig verschwinden können. Es ist deshalb denkbar, dass viele dieser Defekte nur eine normale biologische Variation repräsentieren, und dass sich nur größere Defekte, die auch dann noch bestehen wenn die altersbedingte Reduktion des Knorpelmetabolismus eine Reparation unmöglich machen, zu klinisch evidenten Läsionen entwickeln.

In den letzten Jahren hat die Erkenntnis zugenommen, dass es wegen des stark gesenkten Knorpelmetabolismus im Alter fast unmöglich ist, erwachsenen Gelenkknorpel zu reparieren. Die Forschung auf dem Gebiet von OA beim Pferd hat sich in zwei Richtungen entwickelt: Einerseits wird versucht, bei ganz jungen Fohlen, bei denen der Gelenkknorpelstoffwechsel noch sehr aktiv ist, den Aufbau des Knorpels zu 
Physiology and pathology of the equine joint

beeinflussen. Durch spezifische Trainingsmethoden wird versucht, die Struktur der Grundsubstanz zu stärken und so die Widerstandskraft zu erhöhen. Andererseits ist man auf der Suche nach Molekularmarkern, die frühzeitig auf Gelenksschäden aufmerksam machen, bevor diese unrevidierbar werden. Es ließen sich bereits verschiedene Marker finden, keiner ist jedoch bisher diagnostisch spezifisch für $O A$. Es ist abzusehen, dass in der nahen Zukunft eine Reihe spezifischer Marker zur Verfügung stehen werden mit Hilfe derer eine zuverlässige Diagnostik möglich ist. Hinsichtlich OC hofft man auf aussagekräftige genetische Marker, die für die Selektion in der Zucht eingesetzł werden können. Da die Vererbung jedoch den meisten Schätzungen nach nur 25\% Anteil an phänotypischen Variationen hat, d.h. 75\% durch Umweltfaktoren beeinflusst wird, müssen die Aspekte des Managements und der Tierhaltung genaueren Analysen unterzogen werden.

Schlüsselwörter: Pferd, Gelenk, extrazelluläre Grundsubstanz, Kollagen, Proteoglykane, Osteoarthritis, Osteochondrosis

\section{Introduction}

The capacity of the horse to perform successfully depends on its inherent athletic ability and on the capacity to keep free from diseases and conditions that interfere with soundness. It is not surprising that lameness is the most important cause for wastage in various populations of horses (Rossdale et al. 1985, Todhunter and Lust 1990, Olivier et al. 1997). Joint diseases are the most important single cause of lameness (Todhunter 1992). Therefore, the maintenance of normal joint function is a major concern for the equine veterinarian. An understanding of normal joint structure and function provides the basis for the understanding of joint pathophysiology and hence for the prevention, diagnosis, treatment, and prognostication of joint diseases.

The last decades have seen an explosion in the understanding of the structure and function of synovial joints. Most of the basic work was originally done in laboratory animals, but more recently, considerable original work in the equine species has been reported, using either equine tissues under in vitro conditions, or in vivo. This is exemplified by the fact that 10 of the 71 original full papers in the 2000 issue of Equine Veterinary Journal was related to (articular) cartilage (Rossdale 2001).

The present paper aims at giving a synopsis on the physiology and pathology of the equine synovial joint. This overview can not be comprehensive. Attention will focus on molecular components and on biomechanics and homeostasis of the extracellular matrix of articular cartilage in order to provide a background for the understanding of the concepts and goals of present-day joint research. With respect to pathology, only the two most common joint disorders in the horse, osteoarthritis (OA) and osteochondrosis (OC), will be highlighted as examples of a degenerative and a developmental disorder with entirely different pathogenesis. Finally, some remarks will be made on current trends and ideas in the research on joint function and dysfunction in the horse.

\section{Joint physiology}

\section{Gross anatomy and histology}

The gross anatomy of a synovial joint is characterised by opposing, congruent articular cartilage-covered osseous structures secured by a joint capsule and ligaments and containing synovial fluid. The most important function of the joint is to produce smooth, virtually frictionless motion during movement. This function is realised by the contributions of the synovial fluid, synovial membrane, articular cartilage, and subchondral bone.
The unique properties of these tissues enable the limb to move smoothly, absorbing and dissipating the sometimes heavy loads that are generated during locomotion. Alterations in any of these properties will influence the ability of the cartilage surfaces to glide over one another and may increase the friction within the joint, thus contributing to the occurrence of joint disorders.

The synovial fluid is an ultrafiltrate of plasma, containing ions. Most of the molecules present in plasma in the same concentration, with the exception of hyaluronic acid, which is present at a higher concentration in synovial fluid (Knox et al. 1988). Synovial fluid cellular content is predominantly mononuclear (synovial lining cells, monocytes, and lymphocytes), the remainder being polymorphonuclear leukocytes (Todhunter 1996). Synovial fluid is the medium through which nutrients reach articular cartilage, and intra-articular ligaments have also been shown to derive nourishment from the synovial fluid (Amiel et al. 1986). Synovial fluid is viscous due to its hyaluronic acid (HA) content.

The joint capsule consists of an outer fibrous layer that provides stability to the joint and an inner mucosal lining (synovial membrane). The synovial membrane is a thin, 1-to 3- cell-thick layer that lines the whole interior surface of the joint cavity, except for the articular cartilage. The lack of an intimal basement membrane, the presence of gaps between the synoviocytes, and the proximity of the blood vessels to the intimal surface $(5$ to $10 \mu \mathrm{m})$ facilitate the efflux of the capillary exsudate into the synovial cavity (Todhunter 1996). The synovial membrane is capable of regulating the biochemical environment of the joint passively through the diffusion of substances from the capillaries and actively through the secretion of substances by the synoviocytes. The two main functions normally ascribed to synovial lining cells are phagocytosis (type A cells) and synthesis of HA (type B cells). Synovial lining cells also synthesize the extracellular matrix of the synovium (Henderson and Pettipher 1985).

The subchondral bone is in most cases characterised by a relatively thin subchondral plate. This plate is a compact, cortexlike structure. There is a rather abrupt transition to the cancellous bone that is characteristic of most epiphyses. The subchondral bone provides structural support to the overlying articular cartilage. Its stiffness enables it to support relatively high loads without substantial deformation (Radin and Rose 1986).

The articular cartilage is a relatively acellular tissue (1-5\% chondrocytes) that is avascular, aneural and alymphatic (Palmer and Bertone 1994). It therefore consists for the major part of extracellular matrix (ECM) and can be considered as a largely technical tissue in which the material properties determine to what 
extent the tissue is apt to fulfill its important mechanical role (Kempson 1980). The chondrocytes are the only living matter in cartilage, are highly differentiated, and produce and maintain the extracellular matrix of cartilage. Histologically, 4 layers can be discerned (fig. 1). Adjacent to the joint surface, in the superficial zone, the flattened cells have a tangential arrangement. Via the intermediate or middle zone, where arrangement is more haphazard, the cells become organised in more or less orderly arranged columns perpendicular to the joint surface, the deep zone. The last zone is the calcified zone that is separated from the deep zone by the so-called tidemark of which the exact function is still largely unknown (Redler et al. 1975). At the other side the calcified layer is connected to the subchondral bone plate.

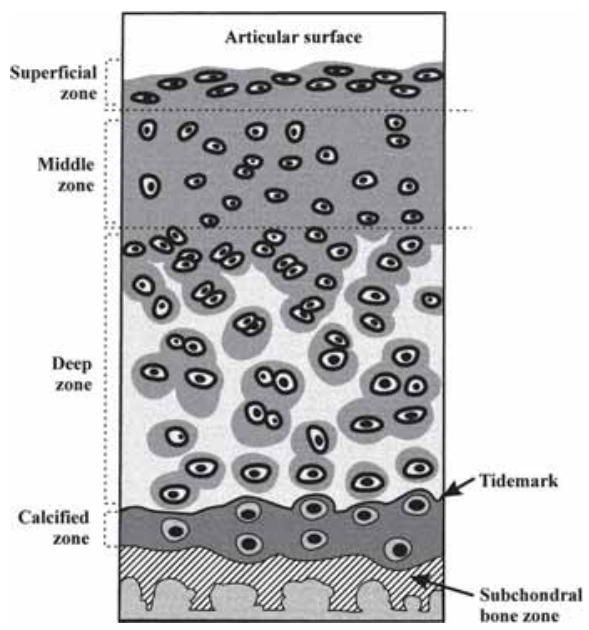

Fig. 1: Semi-schematic drawing of the 4-layer structure of articular cartilage. Note the difference in chondrocyte arrangement in the superficial, middle and deep zones. (Modified from Koopman WJ (ed): Arthritis and Allied Conditions: A textbook of Rheumatology, Vol. 1, $13^{\text {th }}$ ed. Baltimore, Williams \& Wilkins, 1997, p258).

Halbschematische Darstellung der 4 Schichten des Gelenkknorpels. Beachte die unterschiedliche Anordnung der Chondrozyten der oberflächlichen, mittleren und tiefen Zone

Molecular components and ultra-structure of the extracellular matrix

Articular cartilage can only cope with the heavy biomechanical demands that are made upon the tissue because of its unique biochemical composition. The main components of the ECM are collagen, a variety of proteoglycans, and water (Todhunter 1996).

Collagen is present in the form of collagen type II. This is different to most other tissues in the body where the predominant collagen is type I, such as in tendons, ligaments, bone and skin. The basic unit of both types of collagen is the tropocollagen molecule that consists of 3 large chains of amino acids that are wound around each other in a so-called triple helix form (fig. 2). In collagen type II these are $3 \alpha$, -chains that consist of repeating triplets with the amino acid sequence Gly-X-Y where $X$ and $Y$ can be any amino acid. Collagen type I consists of $2 \alpha_{1}$-chains and $1 \alpha_{2}$-chain, has a lesser proportion of hydroxylysine residues and is less richly glycated (Todhunter et al. 1994). The typical tropocollagen molecule consists of about
1000 amino acids (Todhunter 1996). The tropocollagen molecules merge to large fibrils in which they are linked to each other by a variety of cross-links of which the covalent pyridine cross-links are the most important (Eyre and Wu 1995). The substrates for the formation of cross-links are lysyl and hydroxylysyl residues that are linked through mediation of the enzyme lysyl oxidase to form lysylpyridinoline (LP) and hydroxylysylpyridinoline (HP) cross-links respectively. HP cross-links are most abundant in articular cartilage (HP:LP ratio approximately $80: 1$ ).

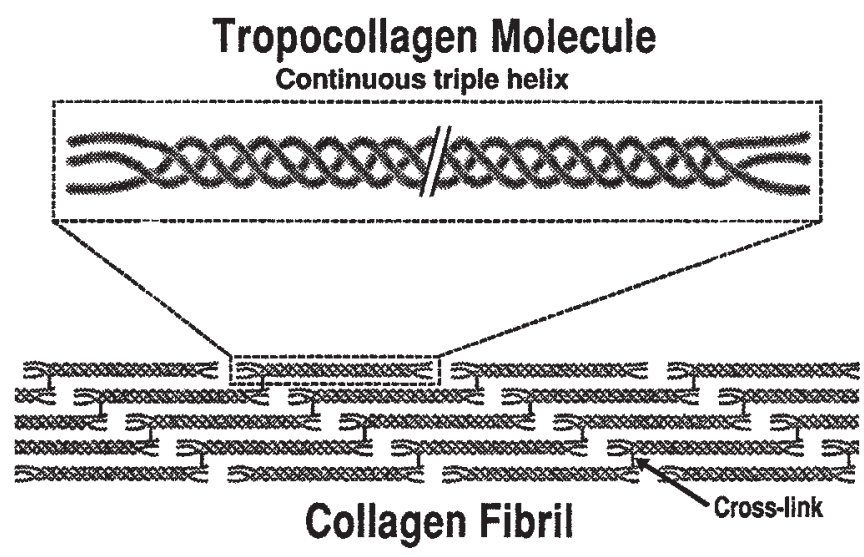

Fig. 2: The tropocollagen molecule that consists of a tightly wound triple helix and its incorporation in the collagen fibril. (Modified from Mcllwraith CW and Trotter GW (eds): Joint Disease in the Horse. Philadelphia, W.B. Saunders, 1996, p205).

Das Tropokollagen-Molekül bestehend aus eng gewundener Triplehelix und sein Einbau in der Kollagenfibrille

Cross-links are formed both intramolecularly and between the tropocollagen molecules within a fibril, thus providing extra strength (Eyre and Wu 1995). The collagen fibrils are arranged according to an arcade-like architecture (fig. 3) in which the pillars are positioned perpendicular to the tidemark and the arches parallel to the joint surface. The individual arcades are linked through cross-links and form in this way a very strong three-dimensional skeleton that resembles the cross vaults that can be seen in medieval churches or castles.

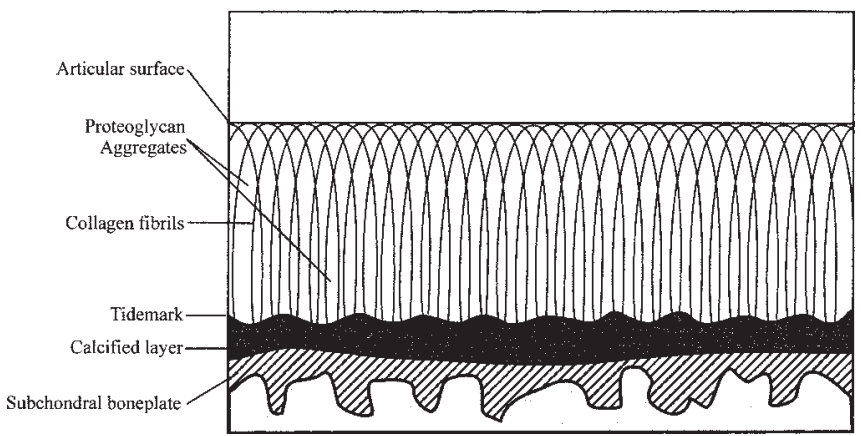

Fig. 3: Arcade-like arrangement of the collagen fibrils within the extracellular matrix. At the articular surface in the superficial layer they have a tangential position, in the deep layer they are positioned perpendicular to the tidemark.

Bogenförmige Anordnung der Kollagenfibrillen innerhalb der extrazellulären Matrix. Im Bereich der Gelenkoberfläche sind sie in der oberflächlichen Schicht tangential gelagert, in der tiefen Schicht senkrecht zur Tidemark 
Apart from collagen type II, minor quantities of other collagens can be found in articular cartilage. These include types V, VII, IX, X, XI, XII and XIV (Ray et al. 1996, Caron 1999). Apart from type $X$ that is found in mineralising cartilage only, these collagens are for the major part thought to play a role in the interaction of non-collagenous constituents of the ECM with collagen type II. Of some of them, the significance is still unclear.

The other major constituents of the ECM of articular cartilage are proteoglycans and water, which are closely associated. Proteoglycans consist by definition of a protein and a glycosaminoglycan (polysaccharide) component. The most important proteoglycan in articular cartilage is the macromolecule aggrecan (Paulsson et al. 1987, Palmer and Bertone 1994). Aggrecan is built up of a core protein with a large number of glycosaminoglycan side chains (fig. 4). These side chains are either keratan sulphate (KS) near the $\mathrm{N}$-terminus of the core protein (fig. 4), or chondroitin sulphate (CS), located over the major part of the core protein. CS is basically a repeat of glucoronic acid and Nacetyl galactosamine, in KS the glucoronic acid has been replaced by galactose and $\mathrm{N}$-acetyl galactosamine by $\mathrm{N}$-acetyl glucosamine. It is important to note that both CS and KS are to

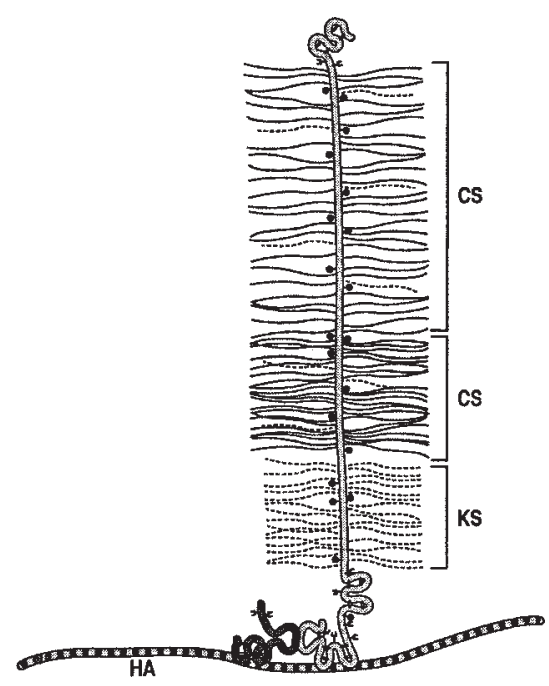

Fig. 4: Schematic representation of an aggrecan molecule attached to hyaluronic acid $(\mathrm{HA})$. The side chains of the core protein of aggrecan consist of the negatively charged hydrophilic keratan sulphate, (KS) chains and a larger number of chondroitin sulphate chains (CS). (Modified from Mcllwraith CW and Trotter GW (eds): Joint Disease in the Horse. Philadelphia, W.B. Saunders, 1996, p206).

Schematische Darstellung eines Aggrekan-Moleküls verbunden mit Hyaluronsäure (HA). Die Seitenketten des Kernproteins des Aggrekan bestehen aus negativ geladenen hydrophilen Keratansulfat-Ketten (KS) und einer Vielzahl von Chondroitinsulfat-Ketten (CS)

a high degree sulphated, having mainly sulphate groups at the 4 or 6 locations of $\mathrm{N}$-acetyl galactosamine and $\mathrm{N}$-acetyl-glucosamine. This sulphation gives them a highly negative charge, which is counteracted by positive ions (mainly $\mathrm{Na}+$ ) resulting in high osmotic pressures, and hence make them very hydrophilic. Within the ECM aggrecan molecules attach to hyaluronic acid, a very large (molecule mass exceeds several thousand kilodalton) non-sulphated glycosaminoglycan which in its turn is connected to the collagen network (Perin et al. 1987). Ag- grecan molecules may attach directly to the collagen fibres too (fig. 5). The hydrophilic proteoglycan aggregates will attract water and thus have a natural tendency to expand. However, swelling is limited as they are trapped within the strong collagen network that will not permit them to become fully satura-

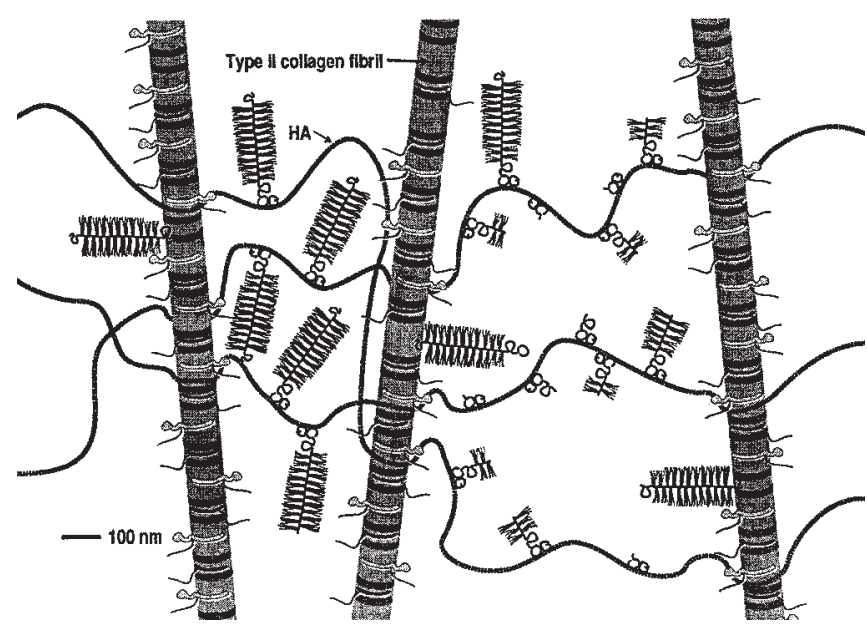

Fig. 5: Schematic drawing of the structure of the extracellular matrix of articular cartilage. The aggrecan molecules (which may be intact or partially cleaved) attach to hyaluronic acid and to the long chains of the non-sulphated glycosaminoglycan hyaluronic acid (HA). In fact, the density of the aggrecan molecules and/or split products is much larger than suggested by this picture. (Modified from Mcllwraith CW and Trotter GW (eds): Joint Disease in the Horse. Philadelphia, W.B. Saunders, 1996, 204)

Schematische Darstellung der Struktur der extrazellulären Gelenkknorpelmatrix. Die Aggrekan-Moleküle, welche intakt oder auch teilweise gespalten sein können, binden an Hyaluronsäure und an die langen Ketten der nicht-sulfatierten Glykosaminoglykan-Hyaluronsäure (HA). Tatsächlich ist die Dichte der Aggrekanmoleküle und/oder deren Bruchstücke viel höher als auf der Abbildung dargestellt

ted. Thus, a very tight and densely packed tissue results in which the osmotic pressure from the proteoglycan aggregates is counterbalanced by the tensile strength of the collagen network. This dense organisation can be beautifully visualised by electron microscopy (fig. 6).

\section{Articular cartilage biomechanics}

Articular cartilage has two major biological functions. First, cartilage has to withstand, transmit and dampen the high forces that are generated by locomotion. Second, cartilage must permit a low-friction movement of skeletal components over each other (Palmer and Bertone 1996).

To comply with the first task, cartilage must be as strong as bone, but may not be as rigid. This is accomplished by the unique combination of proteoglycan aggregates and the collagen network. In this configuration, that can be seen as a steel cable mesh that has been tightened around elastic rubber balls, thus creating an intrinsic tension in the system, the collagen provides tensile strength and the proteoglycan aggregates account for compressive stiffness. When the system is loaded, water will be squeezed out as the external force exceeds the hydrostatic forces until a new equilibrium has been reached. There is a 
strong dampening mechanism because directly after loading the initial deformation will be large when superficially located water is squeezed out, whereas it will take considerably more

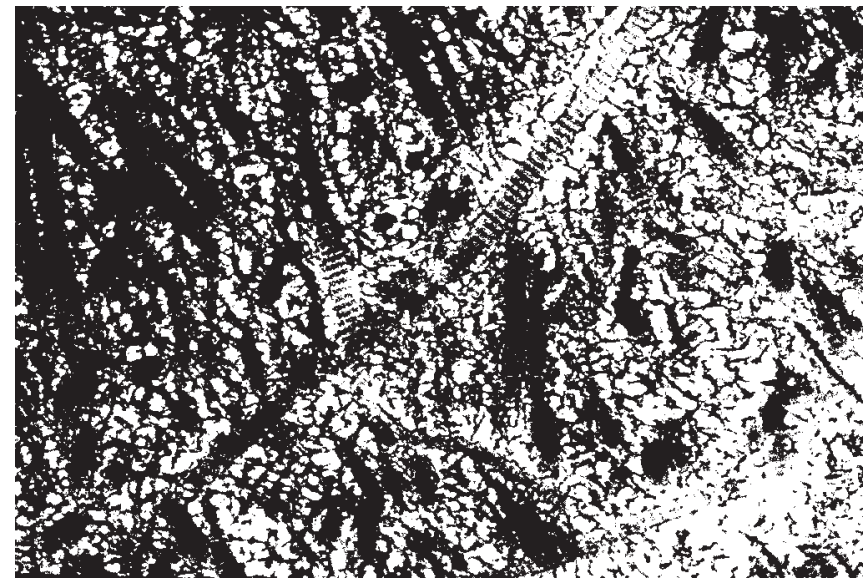

Fig. 6: Electron microscopic photograph of the extracellular matrix of articular cartilage. The space between the collagen fibrils (visible as striated elongated structures) is densely packed with proteoglycan aggregates. (x 26,250).

Elektronenmikroskopische Aufnahme der extrazellulären Gelenkknorpelmatrix. Der Raum zwischen den Kollagenfibrillen, sichtbar als lange quergestreifte Strukturen, ist dicht gepackt mit Proteoglykanaggregaten $(x 26,250)$

time for the deeper located water molecules to flow through the dense ECM. This results in a creep-like behaviour (Palmer and Bertone 1996; fig. 7).

The smooth gliding motion of joint surfaces over each other is made possible in high-load joints through the hydrostatic or "weeping" lubrication system, in fact through the thin film of water that is squeezed out when the joint is loaded. When loads are lower, lubrication is effectuated via the "boundary" lubrication system in which special molecules such as lubricin play a role. Research demonstrating unchanged coefficients of friction after hyaluronidase treatment of synovial fluid suggests that HA has no place in cartilage-on-cartilage lubrication (Mabuchi et al. 1994).

\section{Homeostasis of articular cartilage}

The chondrocytes are responsible of maintaining the vast volume of ECM that surrounds them. They are capable of producing all constituents of the ECM and of a large number of proteolytic enzymes, which help in remodelling the ECM. Among these the matrix metalloproteinases (MMP's) are the most important (Murphy et al. 1990, Birkedal-Hansen et al. 1993). Chondrocytes may be stimulated by external factors such as mechanical loading and they are susceptible to the influences of various growth factors among which Insulin-like Growth Factors 1 and 2 (IGF-1 \& 2) and members of the Transforming Growth Factor $\beta$ (TGF- $\beta$ ) family play an important role (Platt 1996). The chondrocytes are severely limited in their action because of the avascularity of articular cartilage. Transport of nutrients and waste products is by diffusion through the dense ECM, a process that requires loading and unloading of the cartilage as a mechanical pump.

The turnover time of the ECM constituents is variable, but may be long. With respect to proteoglycans it is assumed that various pools exist with different turnover times. These range from 4 days for a part of the pool in 4-week-old rabbits to 1800 days in cartilage from the hip joint of adult human subjects. For collagen, these periods are much longer: 120 years in adult canine cartilage, 350 years in man (Maroudas 1980, Maroudas et al. 1992). Against this background the truthfulness and the inescapability of the 250 years old statement by Hunter that "From Hippocrates to the present age there is universal agreement that ulcerated cartilage is a troublesome thing that when once destroyed is not repaired" becomes clear (Hunter 1743). It is important to realise, however, that this applies to articular cartilage in mature individuals. Metabolism and remodelling

\section{Load}

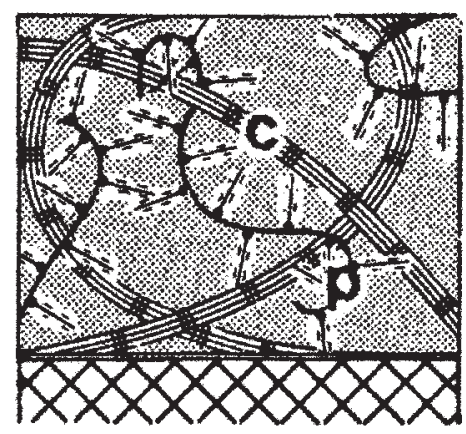

A)

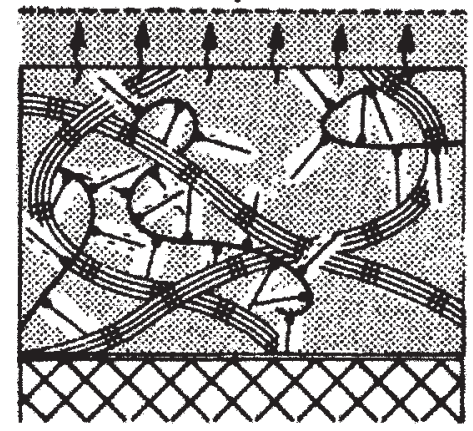

B)

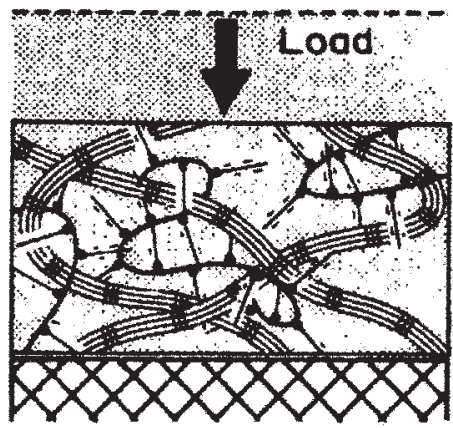

c)

Fig. 7: Creep behaviour of articular cartilage. A: unloaded condition; B: the superficially located water will be squeezed out immediately when load is applied; $C$ : the deeper located water encounters much more resistance, resulting in a slower flow and a deceleration of the yielding of the cartilage until a new equilibrium has been reached. C: collagen fibril; P: proteoglycan aggregates. (Modified from Mcllwraith CW and Trotter GW (eds): Joint Disease in the Horse. Philadelphia, W.B. Saunders, 1996, 20).

Anpassungsverhalten des Gelenkknorpels. A: im unbelasteten Zustand; B: das oberflächlich gebundene Wasser wird unmittelbar nach Belastung ausgepresst; C: das tiefer gebundene Wasser erfährt mehr Widerstand, was in einem langsameren Fluss und verminderter Nachgiebigkeit des Gelenkknorpels resultiert, bis ein neves Gleichgewicht erreicht ist. C: Kollagenfibrille; P: Proteoglykanaggregat 
rate in cartilage from juvenile individuals is several times higher, resulting in a much better capacity for repair (Buckwalter and Mow 1992; Mcllwraith 1996).

\section{Joint pathology}

\section{Osteoarthritis}

Osteoarthritis $(\mathrm{OA})$, also called degenerative joint disease, arthrosis or osteoarthrosis, is a very frequent ailment in both the equine species and man. In man it is largely a disease of elderly people. In the horse, the disease is more prevalent in older horses too, but also relatively young animals are frequently affected. OA can be encountered in every joint. However, most commonly affected are the joints of the distal limbs, namely the metacarpophalangeal and metatarsophalangeal joints and the distal interphalangeal joint (ringbone). OA of the radiocarpal and intercarpal joints is regularly seen in racing Thoroughbreds, and $\mathrm{OA}$ of the distal intertarsal joint (bone spavin) is common in many breeds, including ponies (Pool 1996).

In $\mathrm{OA}$ the equilibrium between the continuous challenging and the remodelling of the ECM has been disturbed. The chondrocytes are not able to cope with demand, which results in a deterioration of the ECM. The deteriorated ECM is less able to withstand the biomechanical challenges that thus will lead to further damage that can not be repaired in time. In this way a vicious circle is started in which the decreasing integrity of the ECM results in increasing vulnerability and hence in an increasing rate of destruction under the continuing biomechanical challenge. Micro-damage to the collagen network will lead to leakage of proteoglycans and cleavage products of these. Chondroitin sulphate and keratan sulphate and CS and KS split products have been identified as early OA markers (Ray et al. 1999). The chondrocytes will upregulate production, but cannot keep up with the pace at which proteoglycans are lost. Finally, they will become exhausted which will lead to an even more rapid depletion of proteoglycans in the ECM. The collagen network, damage to which may be primary in early $O A$ but which is, due to its nature, by far the most resistant part of the ECM, will finally yield too. This results in the macroscopically visible phenomenon of fibrillation (fig. 8). In the last stages of OA only subchondral bone remains over large areas of the joint. By then, the joint is severely impaired in its function and the patient has become invalidated.

Much research has been done on the exact pathogenesis of $\mathrm{OA}$. It is nowadays felt that early ideas on the pathogenesis of OA, abnormal biomechanical forces causing direct damage to cartilage, are too simplistic. Nevertheless, factors that result in excessive loading of certain joints or areas within joints certainly play a role. This is the case with respect to the dorsal rim of the $3^{\text {rd }}$ carpal bone in the racing Thoroughbred that often has a back-in-the-knee conformation, the "step" in the articular cartilage after imperfect healing of a fracture of the $1^{\text {st }}$ phalanx, or simply overweight. The latter factor is extremely important in man (Sturmer et al. 2000) and might have importance in some breeds of horses too. At the other end, OA may be facilitated by poor quality articular cartilage that cannot withstand the high biomechanical loads it is subjected to under normal conditions. Here, hereditary factors may certainly play a role and there are searches ongoing for molecular markers for poor quality collagen type II. Specific families in man and strains of mice are known which have an extreme susceptibility to develop OA at a very young age (Stoop et al. 1999). This type of $\mathrm{OA}$ is not known in the horse. Other theories see changes in the subchondral bone (that, as basis of the cartilage, to a large extent determines the effective loading of it) as a primary aetiologic factor (Radin and Rose 1986). With respect to the development of the disorder, enzymatic degradation of articular cartilage is now recognised as a central feature of $O A$. It is generally agreed that destruction of ECM with proteinases is an integral part of the "final common pathway". Elevated levels of catabolic cytokines such as IL- 1 and TNF- $\alpha$, which may stimulate the production of proteolytic enzymes, have been demonstrated in equine OA. MMP-levels have been proven to be much higher indeed in the synovial fluid from $\mathrm{OA}$ patients than from normal joints (Brama et al. 1998, Clegg et al. 1997). MMP-3 or stromelysin was even specifically elevated in OA samples compared to other MMP's (Brama et al. 2000a). These findings have long been seen as consequence rather than cause. However, they may be more instrumental than once thought. It is now recognised that mechanical forces may be more likely to destroy cartilage indirectly through insult to the subchondral bone, synovial membrane, or chondrocytes and the resulting inflammatory response triggered by the release of cytokines, than through direct damage (Mcllwraith 1996). The combination of extracellular matrix degradation (leading to impairment of the cartilage) and continuing biomechanical challenge of the cartilage then leads to the fatal vicious circle of OA.

\section{Osteochondrosis}

Osteochondrosis (OC) was first described in the horse by Nilsson in 1947, but did not become a clinical concern before the 1970s. Nowadays the disease has a high prevalence in many breeds. It has been estimated that in North-Western Europe 20,000-25,000 foals are born annually that will develop some form of OC. This is about $20-25 \%$ of the population (van Weeren and Barneveld, 1999). The disease is a disturbance of the natural process of endochondral ossification as this takes place in the young growing animal. New lesions can therefore not occur in mature animals, though occult, pre-existing lesions may become clinically manifest at later age. Osteochondrosis is the most important of the so-called developmental orthopaedic diseases (Mcllwraith 1986).

Endochondral ossification basically takes place at two sites of the growing long bone: in the growth plate where almost all increase in length of the bone originates, and at the articular epiphyseal cartilage. Here, the endochondral ossification accounts for the increase in size of the epiphyseal articular surface and for the considerable decrease in cartilage thickness that occurs during the development from foal to adult (Firth and Greydanus 1987). In $\mathrm{OC}$ there are focal areas where this process lags behind, resulting in the formation of so-called cartilage plugs. Histologically the first signs are, apart from the indentation of the ossification 
front, the loss of the normal columnar arrangement of the chondrocytes in the deep layer of the articular cartilage and the forma-

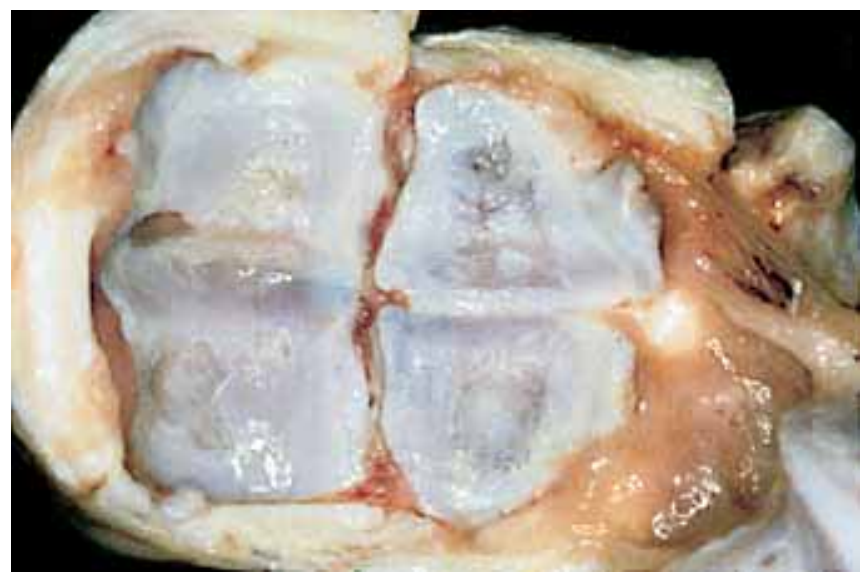

Fig. 8: Severely damaged articular cartilage due to advanced osteoarthritis. Damage to the collagen network has led to fibrillation.

Hochgradig geschädigter Gelenkknorpel bei fortgeschrittener Osteoarthrose. Die Schädigung des Kollagennetzwerks führt zur Auffaserung

tion of clusters of chondrocytes, the so-called chondrones (fig. 9). After this, the failing nutrition of the thickened cartilage may result in necrotic areas and fissures will be formed in these weakened areas under the biomechanical loading. Finally, fragments may be formed that can loosen and become joint mice (fig. 10). linked to the occurrence of the Wobbler syndrome (Wagner et al. 1985).

The pathogenesis of $\mathrm{OC}$ is still unclear. There is common agreement that the disease is multifactorial in origin (Hurtig and Pool 1996) and that both genetical and environmental factors play

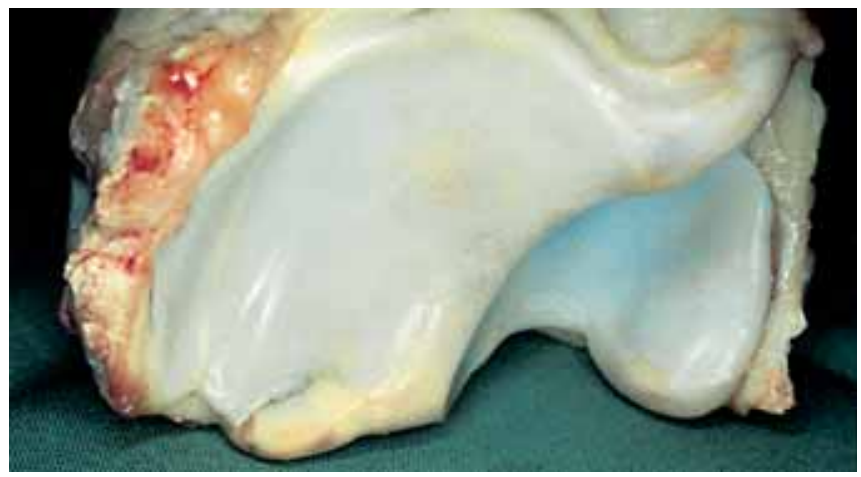

Fig. 10: Characteristic lesion at the intermediate ridge of the distal tibia with a semi-loose fragment.

Charakteristische Läsion mit anhaftendem Fragment am mittleren Gelenkkamm der distalen Tibia

a role. Of the latter category, nutrition and exercise have received most attention. High energy feeding with the use of large amounts of easily digestible carbohydrates has been suggested to be important through the influence on the insulin metabolism and the instrumental role of insulin-like growth factor 1 (IGF-1) in the process of mineralisation of cartilage (Glade and Belling 1986, Ralston 1996). Copper is another nutritional ele-
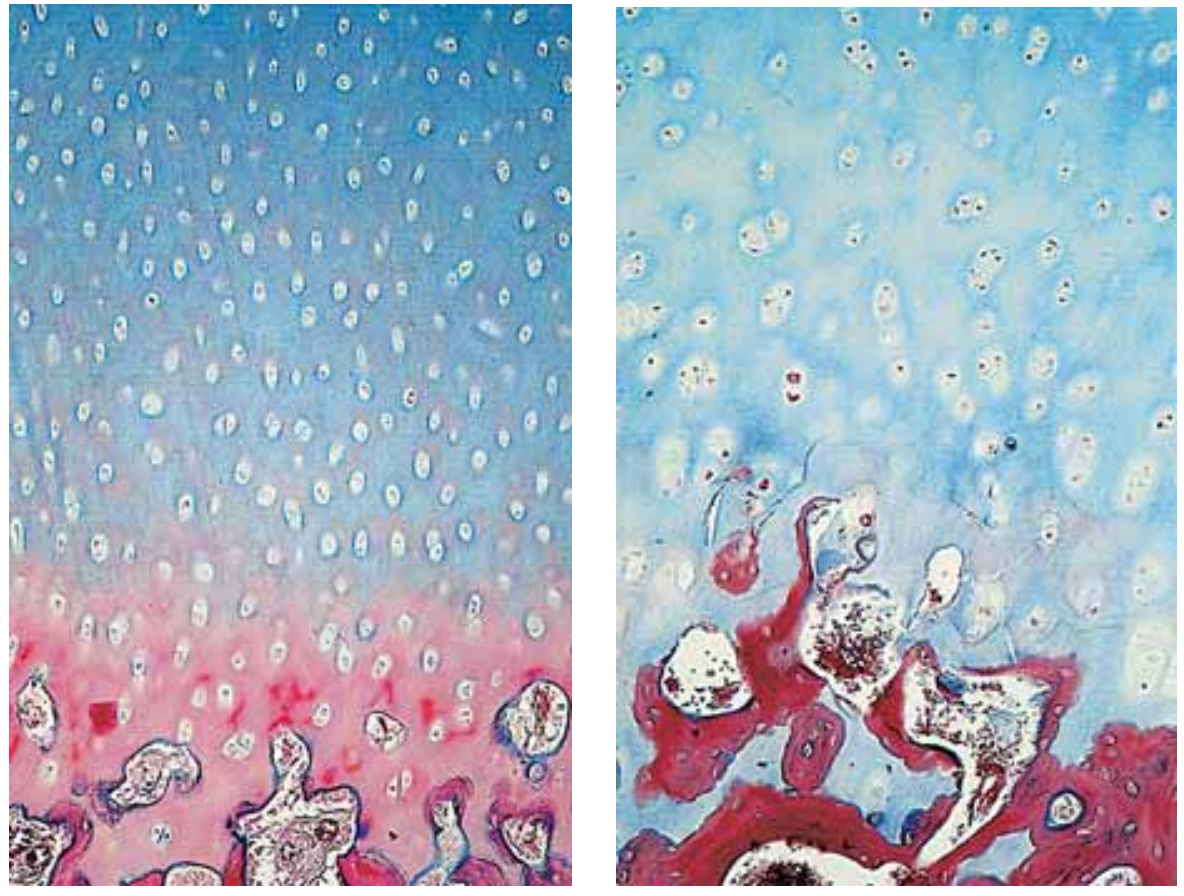

Fig. 9: A: normal histological appearance of the deep and intermediate layer of equine articular cartilage (Azan x100); B: Early histological signs of osteochondrosis: loss of the normal arrangement and chondroneformation (Azan x 100).

A: Normales histologisches Erscheinungsbild der tiefen und mittleren Schicht des equinen Gelenkknorpels (Azan x 100); B: Frühe histologische Anzeichen für Osteochondrose: Verlust der normalen Anordnung und ChrondronBildung (Azan x100).

Osteochondrotic defects, when large, may eventually cause osteoarthritis, however, this is in all cases a secondary event.

Osteochondrosis is most frequently seen in the tarsocrural and femoropatellar joints, but is common in the metacarpophalangeal and metatarsophalangeal joints as well. Though less frequent, $\mathrm{OC}$ has been found in almost every synovial joint of the horse, including the intervertebral facet joints where it has been ment that has been incriminated in the pathogenesis of $\mathrm{OC}$ as it is an essential component of the enzyme lysyl oxidase that is pivotal for the formation of the pyridine cross-links. However, although a copper deficiency can produce OC-like lesions, these are not similar to naturally occurring lesions. Also, the supplementation of copper to young foals and late-pregnancy mares led to contradictory results (Knight et al. 1990, Pearce et al. 
1998). Much effort has been put into the unravelling of the molecular mechanism of OC. Jeffcott and Henson (1998) have given an excellent recent review of this research. Although several differences exist in the molecular characteristics of osteochondrotic and normal cartilage and subchondral bone (Lillich et al. 1997, van de Lest et al. 1999), and also differences in several proteolytic enzymes, especially cathepsin B (Hernandez-Vidal et al. 1998) have been demonstrated, the crucial question of what is cause and what consequence remains. Recently, it has been shown that $O C$ is a much more dynamic process than thought before. A longitudinal radiographic study showed that lesions might come and go within young foals. Five-month-old foals had significantly more lesions than foals aged 11 months (Dik et al. 1999). After a certain moment that may differ per joint, lesions that still exist will remain and may eventually develop into clinical lesions. These findings did not provide clues for the real pathogenesis of $\mathrm{OC}$, but led to the concept that irregularities in the process of endochondral ossification may to a certain extent represent biological variation of a physiological process. Only if the aberrations are so large that they cannot be corrected for in time, i.e. before the metabolism and remodelling rate of the articular cartilage have decreased so far that repair is not possible anymore, they may develop into clinical lesions. The recent finding that the liver copper concentration of the foal at birth is not related to the occurrence of lesions, but is positively correlated to the repair of already existing lesions (van Weeren et al. 2001), supports this concept as it suggests that copper is not involved in the origin of the irregularities of the endochondral ossification, but may be important in the repair phase.

\section{Current trends in equine joint research}

The growing awareness of the truthfulness of Hunter's statement, i.e. of the impossibility to substantially alter the ECM of articular cartilage in mature individuals and hence the impossibility of full repair, has driven synovial joint research into two directions - the manipulation of the developing ECM in juvenile cartilage when this is still possible and the quest for molecular markers as early indicators of damage before this may become irreversible.

The concept of a joint that has a homogeneous biochemical composition at birth, both with respect to proteoglycans (Little and Ghosh 1997) and collagen (Brama et al. 2000b), and is moulded by the influence of exercise into a joint with topographically very heterogeneous biochemical characteristics which specifically match biomechanical demands, has led to the idea that exercise can be used to influence biochemical composition and hence injury resistance (van Weeren et al. 2000, Brama et al. 2001a). This, however, is only possible during a limited period of time at young age. In tendons, where developments are similar though they may have another window in time (Cherdchutham 2001), this concept has already raised the question whether training should be started earlier rather than later (Smith et al. 1999). It must, however, be kept in mind that inappropriate exercise in the young foal may have negative long-term effects (Barneveld and van Weeren 1999). Exercise should therefore be balanced carefully. To find this balance largescale field studies will have to be undertaken, one of which is currently being conducted in New Zealand (Mcllwraith 2000). In the search for molecular markers many candidates have been scrutinised (Lohmander et al. 1992). These include, among others, glycosaminoglycans and glycosaminoglycan split products, various epitopes of collagen (Frisbie et al. 1999), a variety of proteinases most of which belong to the MMP-family (Clegg et al. 1997, Brama et al. 1998, 2000b), and minor components of the ECM such as Cartilage Oligomeric Matrix Protein (COMP) (Misumi et al. 2001). Although many of these were found to be elevated in OA and some, as in the case of MMP3 (Brama et al. 2000b), even more than others, none of these substances were found to be discriminative and indicative for early stage OA. This could not be expected either as in an insidious degenerative ailment such as $O A$ the balance gradually changes from a physiologic homeostasis to a pathologic disequilibrium. This is accompanied by the gradual upregulation of both catabolic and anabolic processes and an increase in waste products in various forms. In an initial stage changes in the concentration or expression of individual candidate mar-kers will not be discernible from normal biological variation. It lies at hand that in the near future, with increasing knowledge of normal levels of a large number of these potential markers and of the influence of physiologic factors such as age, profiles that include a subset of the most suitable markers can be made that may give a good impression of the health status of a given joint.

A third, rather new and potentially promising approach of equine degenerative joint disease is gene therapy. DNA can be expressed in a host, leading to the synthesis of proteins that are not or not sufficiently produced by the host such as proteinase or cytokine inhibitors, or matrix constituents. However, many factors are still uncertain. It is still difficult to find good vectors for the introduction of the DNA-constructs and the time-span during which these are expressed is usually too limited to affect chronic conditions. Further, the production of proteins such as anti-TNF- $\alpha$ (Frisbie and Mcllwraith 2000) may help in alleviating the ailment, but is not a causal therapy. The production of matrix constituents presumes that the failure to produce these by the chondrocytes of the host is a primary cause, and not for instance the impossibility to incorporate them into the tightly packed, non-vascularised and relatively acellular ECM. Gene therapy might therefore not be the panacea some think it to be. It is concluded that our knowledge about the molecular components and homeostasis of the equine synovial joint has vastly increased in the past few decades. Equine joint research has definitively passed the macroscopic and microscopic era and is where it should be: at the molecular and cellular level. $\mathrm{Ne}$ vertheless, we are still far away from a complete understanding of how a joint functions. Vast unexplored areas remain. Hesitatingly, the first publications appear on the biochemical composition of equine subchondral bone (Brama et al., 2001 b,c), as yet without the badly needed validated biomechanical analysis of what the differences that are found really mean. The equine chondrocyte is still largely a black box. Although chondrocyte cultures are common, the in situ behaviour has virtually not been studied. In the opinion of the authors it is the complex 
interaction between chondrocyte and extracellular matrix under the influence of biomechanical loading where the clue for most disorders must be sought. Little is known about signal transduction and intercellular communication and the pathways through which remodelling of the ECM is regulated. We now have reasonable knowledge of the major constituents of the $E C M$, but there are many smaller molecules such as decorin, biglycan, the collagens V, VII, IX XI, XII, XIV and COMP of whose function still little is known. It may be assumed that, with increasing knowledge in these areas, our understanding and hence our possibilities for science-based intervention increase. It will also shed more light on the usefulness of the wide variety of medications that are currently used and widely advertised. Many of these are promoted using evocative semi-scientific arguments and are based on not more than anecdotal or circumstantial evidence. Some of them are supported by reasonable scientific evidence, such as hyaluronic acid. In that case, however, the originally proposed way of action appeared to be a bit too simplistic as this, very viscous, drug acts as an anti-inflammatory agent rather than as a lubricant.

With respect to OC, genetic markers have been advocated as the solution of the problem. Although such markers may be useful, it should not be forgotten that the average estimated heritability of $O C$ is about 0.25 . This means that $75 \%$ of the phenotypical variation can be explained by environmental factors. In a recent study on 25 differently managed studs Valette et al. (2000) found a large variation in the prevalence of OC. Therefore, it seems indicated that research in OC should follow two pathways: an in-depth study of the process of endochondral ossification at a molecular level including the genetic background, and large-scale more epidemiological studies on the influence of a variety of management aspects.

\section{References}

Amiel, D., Abel, M.F., Kleiner, J.B., Lieber, R.L. and Akeson, W.H. (1986): Synovial fluid nutrient delivery in the diathrodial joint: An analysis of rabbit knee ligaments. J. Orthop. Res. 4, 90-95.

Barneveld, A. and van Weeren, P.R. (1999): Conclusions regarding the influence of exercise on the development of the equine musculoskeletal system with special reference to osteochondrosis. Equine vet. J. Suppl. 31, 1121-19.

Birkedal-Hansen, H., Moore, W.G.I., Bodden, M.K., Windsor, L.J., Birkedal-Hansen, B., DeCarlo, A. and Engler, J.A. (1993): Matrix Metalloproteinases: A Review. Crit. Rev. Oral Biol. Med. 4, 197-250.

Brama, P.A.J., TeKoppele, J.M., Beekman, B., Van Weeren, P.R. and Barneveld, A. (1998): Matrix metalloproteinase (MMP) activity in equine synovial fluid: influence of age, osteoarthritis and osteochondrosis. Ann Rheum. Diseases 57, 697-699.

Brama, P.A.J., TeKoppele, J.M., Beekman, B., van El, B., Barneveld, A. and van Weeren, P.R. (2000a): Influence of development and joint pathology on stromelysin enzyme activity in equine synovial fluid. Ann. Rheum. Dis., 59, 155-157.

Brama, P.A.J., TeKoppele, J.M., Bank, R.A., Barneveld, A. and van Weeren, P.R. (2000b): Functional adaptation of equine articular cartilage: the formation of regional biochemical characteristics up to age one year. Equine vet. J., 32, 217-221.

Brama, P.A.J., TeKoppele, J.M., Bank, R.A., Barneveld, A. and van Weeren, P.R. (2001 a): The development of biochemical heterogeneity of articular cartilage from neonatal to adult and the influence of exercise. Equine Vet. J., in press.
Brama, P.A.J., TeKoppele, J.M., Bank, R.A. and van Weeren, P.R. (2001 b): Training affects the collagen framework of subchondral bone in foals. Vet. J., in press.

Brama, P.A.J., TeKoppele, J.M., Bank, R.A., van El, B. and van Weeren, P.R. (2001c): The natural maturation process of subchondral bone in the foal and the influence of physical activity. Equine vet. J., in press.

Buckwalter, J.A. and Mow, D.C. (1992): Cartilage repair in osteoarthritis. In: Osteoarthritis. Diagnosis and Medical/Surgical Management. Eds: R.W. Moskowitz, D.S. Howell, V.M. Goldberg, and H.J. Mankin, W.B. $2^{\text {nd }}$ ed., W.B. Saunders, Philadelphia, 71-107.

Caron, J.P. (1999): Synovial joint biology and pathobiology. In: Equine Surgery, Eds: J.A. Auer and J.A. Stick, $2^{\text {nd }}$ ed., W.B. Saunders, Philadelphia, 665-677.

Cherdchutham, W. (2001): The equine superficial digital flexor tendon: the influences of exercise on early development and of diathermy on tendon healing. Thesis, Utrecht University

Clegg, P.D., Coughlan, A.R., Riggs, C.M. and Carter, S.D. (1997): Matrix metalloproteinases 2 and 9 in equine synovial fluids. Equine vet. J. 29, 343-348.

Dik, K.J., Enzerink, E. and van Weeren, P.R. (1999) Radiographic development of osteochondral abnormalities, in the hock and stifle of Dutch Warmblood foals, from age 1 to 11 months. Equine vet. J. Suppl. 31, 9-15.

Eyre, D.R. and Wu, J.J. (1995) Collagen structure and cartilage matrix integrity. J. Rheumatol. Suppl. 43, 82-85.

Firth, E.C. and Greydanus, Y. (1987): Cartilage thickness measurements in foals. Res. Vet. Sci. 42, 35-46.

Frisbie, D.D., Ray, C.S., lonescu, M., Poole, A.R., Chapman, P.L. and Mcllwraith, C.W. (1999): Measurement of synovial fluid and serum concentrations of the 846 epitope of chondroitin sulfate and of carboxy propeptides of type II procollagen for diagnosis of osteochondral fragmentation in horses. Am. J. Vet. Res. 60, 306-309.

Frisbie, D.D. and Mcllwraith, C.W. (2000): Evaluation of gene therapy as a treatment for equine traumatic arthritis and osteoarthritis. Clin.Orthop. Rel. Res. Suppl. 379, 273-287.

Glade, M.J. and Belling, T.H. (1986): A dietary etiology for osteochondrotic cartilage. J. Equine Vet. Sci. 6, 151-155.

Henderson, B. and Pettipher, E.R. (1985): The synovial lining cell: Biology and pathobiology. Semin. Arthritis Rheum. 15, 1-32.

Hernandez-Vidal, G., Jeffcott, L.B. and Davies, M.E. (1998): Immunolocalization of Cathepsin B in equine dyschondroplastic cartilage. Vet. J. 156, 193-201.

Hunter, W. (1743): On the structure and disease of articular cartilage. Philos. Trans. R. Soc. Lond. 9, 267.

Hurtig, M.B. and Pool, R.R. (1996): Pathogenesis of equine osteochondrosis. In: Joint Disease in the Horse, Eds: C.W. Mcllwraith and G.W. Trotter, W.B. Saunders, Philadelphia, 362-383.

Jeffcott, L.B. and Henson, F.M.D. (1998): Studies on growth cartilage and their application to aetiopathogenesis of dyschondroplasia (osteochondrosis). Vet. J. 126, 177-192.

Kempson, G.E. (1980): The mechanical properties of articular cartilage. In: The joints and synovial fluid, volume II. Ed: L. Sokoloff. Academic Press. New York, 177-238.

Knight, D.A., Weisbrode, S.E., Schmall, L.M., Reed, S.M., Gabel. A.A., Bramlage, L.R. and Tyznik, W.I. (1990): The effects of copper supplementation on the prevalence of cartilage lesions in foals. Equine vet. J. 22, 426-432.

Knox, P. Levick, J.R. and McDonald, J.N. (1988): Synovial fluid. Its mass, macromolecular content, and pressure in major limbs of the rabbit. Q. J. Exp. Physiol. 73, 33-46.

Lillich, J.D., Bertone, A.L., Malemud, C.J., Weisbrode, E., Ruggles, A.J. and Stevenson, S. (1997): Biochemical, histochemical and immuno-histochemical characterisation of distal tibial osteochondrosis in horses. Am. J. Vet. Res. 58, 89-98.

Little, C.B. and Ghosh, P. (1997): Variation in proteoglycan metabolism by articular chondrocytes in different joint regions is determined by post-natal mechanical loading. Osteoarthritis and Cartilage 5, 49-62. 
Lohmander, L.S., Lark, M.W., Dahlberg, L., Walakovits, L.A. and Roos, H. (1992): Cartilage matrix metabolism in osteoarthritis: Markers in synovial fluid, serum, and urine. Clin. Biochem. 25, 167-174.

Mabuchi, K., Tsukamoto, Y., Obara, T. and Yamaguchi, T. (1994): The effect of additive hyaluronic acid on animal joints with experimentally reduced lubricating ability. J. Biomed. Mater. Res. 28, 865-870.

Maroudas, A. (1980) Metabolism of cartilaginous tissues: A quantitative approach. In: Studies in Joint Disease, vol. I, Eds: A. Maroudas and E.J. Holborow, Pitman Medical, Tunbridge Wells, 59-86.

Maroudas, A., Palla, G. and Gilav, E. (1992): Racemization of aspartic acid in human articular cartilage. Connect. Tissue Res. 28, 161169

Mcllwraith, C.W. (2000): Global Equine Research Alliance to reduce musculoskeletal injury in the equine athlete. Equine vet. Educ. (Am. Ed.) 2, 339-341.

Mcllwraith, C.W. (1986): Incidence of developmental joint problems. In: AQHA Developmental Orthopedic Disease Symposium, Ed: C.W. Mcllwraith, AQHA, Amarillo, 15-20.

Mcllwraith, C.W. (1996) General pathobiology of the joint and response to injury. In: Joint disease in the horse. Eds: C.W. Mcllwraith and G.W. Trotter. Saunders. Philadelphia, 40-70.

Misumi, K., Vilim, V., Clegg, P.D., Thompson, C.C.M. and Carter, S.D. (2001): Measurement of cartilage oligomeric matrix protein (COMP) in normal and diseased equine synovial fluids. Osteoarthritis and Cartilage 9, 119-127.

Murphy, G., Hembry, R.M., Hughes, C.E., Fosang, A.J. and Hardingham, T.E. (1990): Role and regulation of metalloproteinases in connective tissue turnover. Bioch. Soc. Trans. 18, 812-815.

Nilsson, F. (1947): Hästens goniter. Svensk Vetidn. 52, 1-14.

Olivier, A., Nurton, J.P. and Guthrie, A.J. (1997): An epizoological study of wastage in Thoroughbred racehorses in Gauteng, South Africa. J. S. Afr. Vet. Ass. 68, 125-129.

Palmer, J.L. and Bertone A.L. (1996): Joint biomechanics in the pathogenesis of traumatic arthritis. In: Joint disease in the horse. Eds: C.W. Mcllwraith and G.W. Trotter. Saunders. Philadelphia, 104-1 19.

Palmer, J.L. and Bertone, A.L. (1994): Review article: joint structure, biochemistry and biochemical disequilibrium in synovitis and equine joint disease. Equine Vet. J. 26, 263-277.

Paulsson, M., Morgelin, M., Weidemann, H., Beardmore-Gray, M., Dunham, D., Hardingham, T., Heinegard, D., Timpl, R. and Engel, J. (1987): Extended and globular protein domains in cartilage proteoglycans. Biochem. J. 245, 763-772.

Pearce, S.G., Firth, E.C., Grace, N.D. and Fennessy, P.F. (1998): Effect of copper supplementation on the evidence of developmental orthopaedic disease in pasture-fed New Zealand Thoroughbreds. Equine vet. J. 30, $211-218$.

Perin, J.P., Bonnet, F., Thurieau, C. and Jolles, P. (1987): Link protein interactions with hyaluronate and proteoglycans. Characterization of two distinct domains in bovine cartilage link proteins. J. Biol. Chem. 262, 13269-13272.

Platt, D. (1996): Articular cartilage homeostasis and the role of growth factors and cytokines in regulating matrix composition. In: Joint disease in the horse. Eds: C.W. Mcllwraith and G.W. Trotter. Saunders. Philadelphia, 29-40.

Pool, R.R. (1996): Pathologic manifestations of joint disease in the athletic horse. In: Joint disease in the horse. Eds: C.W. Mcllwraith and G.W. Trotter. Saunders. Philadelphia, 87-104.

Radin, E.L. and Rose, R.M. (1986): Role of subchondral bone in the initiation and progression of cartilage damage. Clin. Orthop. 213, $34-40$.

Ralston, S.L. (1996) Hyperglycaemia/hyperinsulinaemia after feeding a meal of grain to young horses with osteochondrosis dissecans (OCD) lesions. Pferdeheilk. 12, 320-322.

Ray, C.R., Poole, A.R. and Mcllwraiith, C.W. (1996): Use of synovial fluid and serum markers in articular disease. In: Joint Disease in the Horse, Eds: C.W. Mcllwraith and G.W. Trotter, W.B. Saunders, Philadelphia, 203-216.
Redler, I., Mow, V.C., Zimny and Mansell J. (1975): The ultrastructure and biomechanical significance of the tidemark of articular cartilage. Clin. Orthop. 112, 357-362.

Rossdale, P.D. (2001): Reflections past and future (editorial). Equine Vet. J. 33, 1

Rossdale, P.D., Hopes, R., Wingfield Digby, N.J. and Offord, K. (1985): Epidemiological study of wastage among racehorses 1982 and 1983. Vet. Rec. 1 16, 66-69

Smith, R.K., Birch, H., Patterson-Kane, J., Firth, E.C., Williams, L., Cherdchutham, W., Van Weeren, P.R. and Goodship, A.E. (1999): Should equine athletes commence training during skeletal development? Changes in tendon matrix with development, ageing, function, and exercise. Equine vet. J. Suppl. 30, 201-209.

Stoop, R., van der Kraan, P.M., Buma, P., Hollander, A.P., Billinghurst, R.C., Poole, A.R. and van den Berg, W.B. (1999): Type II collagen degradation in spontaneous osteoarthritis in $\mathrm{C} 57 \mathrm{Bl} / 6$ and $\mathrm{BALB} / \mathrm{C}$ mice. Arthritis Rheum. 42, 2381-2389.

Sturmer, T., Gunther, K.P. and Brenner, H. (2000): Obesity, overweight and patterns of osteoarthritis: the Ulm Osteoarthritis Study. J. Clin. Epidemiol. 53, 307-313.

Todhunter, R.J. (1996): Anatomy and physiology of synovial joints. In: Joint Disease in the Horse, Eds: C.W. Mcllwraith and G.W. Trotter, W.B. Saunders, Philadelphia, 1-28.

Todhunter, R.J., Wootton, J.A., Lust. G. and Minor, R. R. (1994) Structure of equine type I and type II collagens. Am. J. Vet. Res. 55, 425431.

Todhunter, R.J. and Lust, G. (1990): Pathophysiology of synovitis: Clinical signs and examination in horses. Comp. Cont. Educ. Pract. Vet. 12, 980-992

Todhunter, R.J. (1992) Synovial joint anatomy, biology, and pathology. In: Equine Surgery, Ed: J.A. Aver, W.B. Saunders, Philadelphia, 844 866.

Valette, J.P., Blanchard, G, Paragon, B.M. and Denoix, J.M. (2000): Bilan de l'enquête sur l'élevage équin en Basse-Normandie: suivi zootechnique et statut radiologique des poulains. Epidémiol. et Santé Anim., 27-37

Van Weeren, P.R., Knaap, J. and Firth, E.C. (2001): The influence of liver copper status of mare and newborn foals on the development of osteochondrotic lesions. Submitted.

Van Weeren, P.R., Brama, P.A.J. and Barneveld, A. (2000) Exercise at young age may influence the final quality of the equine musculoskeletal system. Proc. Am. Assoc. Equine Pract. 46, 29-35.

Van Weeren, P.R. and Barneveld, A. (1999): Study design to evaluate the influence of exercise on the development of the musculoskeltal system of foals up to age 11 months. Equine vet. J. Suppl. 31, 4-8.

Van de Lest, C.H.A., Van den Hoogen, B.M., Van Weeren, P.R., Brouwers, J.F.H.M., Van Golde, L.M.G. and Barneveld, A. (1999): Changes in bone morphogenic enzymes and lipid composition of equine osteochondrotic subchondral bone. Equine vet. J. Suppl. 31, 31-37.

Wagner, P.C., Grant, B.D., Watrous, B.J., Appell, L.H. and Blythe, L.L. (1985): A study of the heritability of cervical vertebral malformation in horses. Proc. Am. Assoc. Equine Pract. 31, 43-50.

P.R. van Weeren DVM PhD Dipl ECVS Dipl RNVA

Department of Equine Sciences

Faculty of Veterinary Medicine

University of Utrecht

Yalelaan 12

NL-3584 CM Utrecht

The Netherlands

Phone: $++-31-30-2531062 / 1350$

Fax: ++-31-30-2537970

Email: r.vanweeren@vet.uu.nl 